Melanism is the opposite of albinism. It is the darkness of color resulting from abnormal development of melanin, a black or brown pigment in the skin, hair, feathers, etc. of animals. The species affeoted is known as a melano.

The silver black fox is merely a melanistic phase of the red fox. A fine specimen of a melano Franklin's Ground Squirrel (Spermophyle) or Bush Gopher was donated to the Provincial Museum by Miss Doris Thompson of Carlyle, May 14, 1925. -- Editor.

\title{
FISH
}

This hardly comes under the heading of "Mammals" even although many fish stories have been told about them.

Mr. Shaw reports from Yorkton that hundreds of Brook Sticklebacks were found dead in York lake, four miles south of that city, this spring. Many suckers also were killed. This is a shallow lake and perhaps the depth of the ice was responsible for the loss.

The specimens were identified by Dr. D.S. Rawson, of the University of Saskatchewan.

Readers will be interested to know that an illustrated check list of the fishes of Saskatchewan, has been written by Dr. Rawson and was published only this spring. Copies may be obtained from the Department of Natural Resources and Industrial Development.

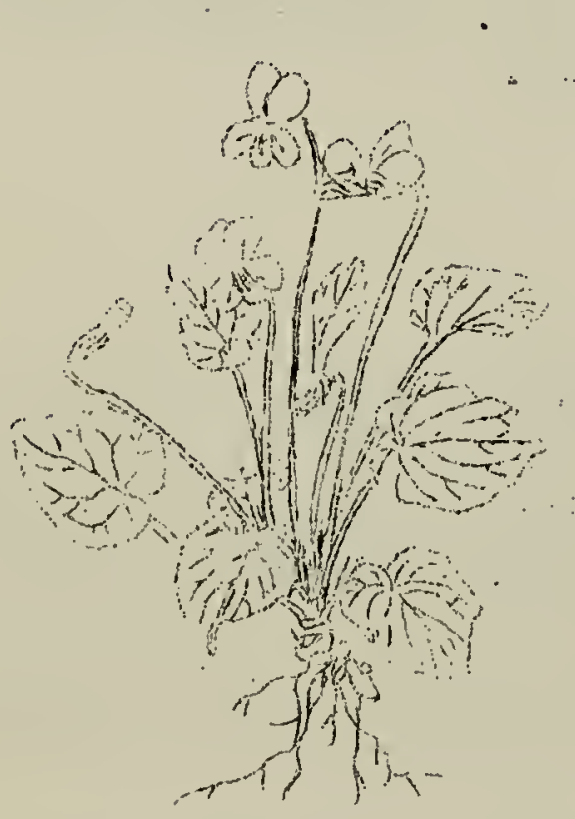

\section{BOTANY SECTION}

our wild plants got away to an early start this spring, many of them producing flowers and seeds two weeks or more earlier than usual. It was a case of "The early bird gets the worm" for many of them met. the fate of some of our semihardy garden perennials by the devastating frosts which swept across the Province on the nights of May 22 and 23. It is to be hoped that our wild fruits are not too badly damaged, but we are keeping our fingers crossed.

More wild-flower observations are solicited and welcomed. If we can be of any service to you in making identifications we will be glad to do so. Mr. A.C. Budd, of Swift Current Experimental Station, and Dr. R.C. Russell, of the University of Saskatohewan, will also be plieased to assist you.

It will not be long before the Illles are again in bloom. We request all of our members to spread among their friends the necessity for the conservation of this, our floral emblem. Perhaps it would not be too much trouble to place a small sign on a roadside post near a patch of these flowers reading, "THE WESTERN LILY IS OUR PROVINC IAI ENBIENM - - PRESERVE THEM FOR OTHERS TO ENJOY." 
KAMSACK -- Mrs. W. Buceuk (May 4)

"It seems to me that our farm, section 33, $T 29, R 31$, W 1st, must be particularly well suited for wild flowers. This year already we have had crocuses on a sandy hill, and today I found, near the swamp, what I think are Kidney-leaved violets. The Canada Violets are also blossoming. Not many years ago I used to pick Crowfoot Violets on a hill near here, but $I$ have not been there lately. Later. on, I expect to find Lady's slippers growing quite near the highway and Western Red Lilies in the meadow where buttercups are already blooming (May 1). I am also hoping to find some more Indian Pipes this year. Last year we found them in our raspberry patch.

I am particularly pleased to see the articles on flowers - the one on violets, for instance. There are so many flowers whose names I do not know and as yet I have been unable to obtain a really good book, giving the detalls I would like.

I would be interested to learn the name of a small flower that grows near the edge of a swampy muskeg near here. From a tiny rosette of leaves rises a stern about three or four inches high. This stem has, at the top, two or three flowers, like miniature primula flowers in shape and color. They bloom about the beginning of June, about the same time as the Marsh Marigolds and in some places they almost cover the ground."

(I think the plant to which you refer is the Mealy Primrose. Ed.)

\section{"PRAIRIE FLORA"}

Readers will join with us in extending congratulations to Arch $\mathrm{C}$. Budd, a member of our Directorate and range botanist at the Swift Current federal experimental farm.

Recently he has finished compiling a book describing in detail the flowering wild plants of the prairies, extending from Manitoba to the foot-hills of the Rockies. This "Flora of the Farming and Ranching Areas of the Canadian Prairies" was written primarily for the Saskatchewan agricultural-representative service and about 200 copies have been printed and are now in use. A copy is available for your examination at the Provincial Museum in Regina.

Pages from this book describing our Pentstemon species and Wild Geraniums have appeared in this and the last issue of the BLUE JAY. The entire book of 280 pages is written like that and will prove a boon to western botanists.

"It has been my aim in compiling this book to set down facts about plant life that every homesteader can understand," Mr. Budd said. "I know what that will mean because I homesteaded 18 miles east of Swift Current in 1910."

Nir. Budd plans, in time, to have this book published for general circulation, and we sincerely hope that this will be done. He will also incorporate with it the section from ferns to junipers.

"They say," writes Mr. Budd, "that "fools step in where angels fear to tread,' but I have been waiting so long for a flora of the western prairies to be written by an expert that I thought an amateur would have to fill the breach until a more technical person supplies our needs."

The BLUE JAY commends the author for the splendid work that he has turned out and wishes him every success in his venture.

INDIAN HEAD -- T. PEIIY

"Congratulations on the new BLUE JAY. It should prove of great value

to all amateur nature lovers. 
We were especially interested in your list of early wild flowers and made use of it to stimulate interest in our grade eight class. With it as a guide we divided our class into four parts and made a census of the birds and flowers to be seen within a radius of half a mile from our school. Besides finding seventeen species of birds we were able to identify crocus, moss phlox, early cinquefoil, dandelion, violet, blue toad-flax and golden bean. (Cymopterus and Hoary Puccoon were also found and sent in for identification).

We would like to see other group-lists for definite periods of the year."

FIOWERS IN MAY

I.T. Carmichaei

It was Sunday morning, May 15: the dead-line date for material of this issue. A few feet from the window a robin was busily at work adding new twigs, dead grass and bits of string to its nest, and shaping it with its breast as it fluttered its wings and revolved in circles. On an adjacent tree, its mate, dressed up for the occasion, was showing off his new plumage and lustily cheering it on. Not more than thirty feet away, half hidden by the leaves of a maple at the corner of the house, a Baltimore Oriole tried to steal the spotlight from this domestic scene by singing to its heart's content. A smoky haze filled the air; there was no wind; it was a dry, but otherwise ideal, day for observing the beauties of nature.

Curiosity as to how the flowers were coming along this spring prompted us to jump in the car and head for the QuAppelie Valley, some twenty-five miles north of Regina.

We soon learned that the hills of the Valley are not a pretty sight this spring. In the complete absence of rain, the grass, which earlier had shown a tinge of green, had withered and turned brown again. Yet as we descended from the wind-swept sumit to the talley below, brave little flowers greeted us here and there on every side.

Peeping out from among the dead growth, were the Early Cinquefoils, some having already gone to seed, others with their. yellow petals centred in or ange, and small clumps of Nuttal's Yellow Violet - a flower too beautiful for such a setting. Most of the Moss Phlox had shed their white petals and the Crocuses had already gone to seed; patches of their plumelike heads showing a purple tinge. The Succulent Buffalo-bean grew in patches here and there. Some still showed their light blue pea-like blossoms, while others already exhibited clusters of luscious looking fruit, already tinged with red and as large as a marble.

The Pale Comandra, with its white star-like blossoms, seemed to enjoy its habitat and were on every side, as were numerous plants of the Common Prairie onion. Few blossoms of the Bladder-pod remained, but here and there the small mustard-like blossoms could be seen terminating the prostrate branches, bearing the globular and swollen fruit pods.

On the steepest slopes among the Cactus leaves were the stunted shrubs of Sumac or Small Skunk Bush with yellow blossoms but no leaves as yet... The bright green patches of the Creeping Juniper relieved the bleakness of the hill. Most of the creeping branches were laden with fruit; blue-green in color. 